\title{
Wasiat Wajibah Kepada Anak Angkat Non Muslim dan Anak Tiri (Formulasi Hukum Wasiat Wajibah dalam Pasal 209 Kompilasi Hukum Islam di Indonesia dan Perkembangannya)
}

\author{
Khotifatul Defi Nofitasari, M.H \\ Institut Agama Islam Negeri Ponorogo \\ devimaulana007@gmail.com
}

\begin{abstract}
A Compilation of Islamic Law (KHI) in Indonesia includes wasiat wajibah will not for grandchildren whose parents die and are covered by uncles like in other muslim countries. Wasiat wajibah provided for in article 209 are intended for adopted children and adoptive parents. The development of the wasiat wajibah in Indonesia is much developed through breakthroughs of the legal judge Ijtihad. Not only to adovtive children and adoptive parents, wasiat wajibah in Indonesia are also given to non muslim children and non muslim families through a decision on the Kasasi level as a reference. At present, a broader discussion of the object of giving a will must recur. The discussion was concerned with the granting of wasiat wajibah to stepchildren, although this was still a pros and cons among mujtahid, in this case the panel of judges. This type of research is library research with descriptive analytic methods. The object of the research study is article 209 Compilation of Islamic Law and several wasiat wajibah of non muslim and stepchildren. This research uses a sociological normative perspective. The purpose of the research is to examine more deeply about the legal formulation of the wasiat wajibah testament in Indonesia, both the applicable is article 209 Compilation of Islamic Law, the jurisprudence of wasiat wajibah and its development.
\end{abstract}

Keyword: Wasiat Wajibah, Legal Formulation, Compilation of Islamic Law

Abstrak: Kompilasi Hukum Islam (KHI) di Indonesia memasukkan adanya wasiat wajibah bukan kepada cucu yang telah ditinggal mati orangtuanya dan terhijab oleh paman seperti halnya di negaranegara muslim lainnya. Wasiat wajibah yang diatur dalam pasal 209 ditujukan kepada anak angkat dan orang tua angkat. Perkembangan penerapan wasiat wajibah di Indonesia jauh berkembang melalui terobosan-terobosan hukum ijtihad hakim. Tidak hanya kepada anak 
dan orang tua angkat, wasiat wajibah di Indonesia juga diberikan kepada anak atau keluarga non muslim dengan adanya putusan tingkat kasasi yang menjadi rujukan. Dewasa ini, pembahasan lebih luas tentang objek pemberian wasiat wajibah di Indonesia kembali terjadi. Pembahasan tersebut berkenaan dengan adanya pemberian wasiat wajibah kepada anak tiri, walaupun hal tersebut masih menjadi pro dan kontra diantara para mujtahid dalam hal ini majelis hakim. Jenis penelitian ini adalah penelitian pustaka (library research) dengan metode analitis deskriptip analitik. Objek kajian penelitian ini adalah Pasal 209 Kompilasi Hukum Islam dan beberapa putusan wasiat wajibah kepada non muslim serta anak tiri. Penelitian ini menggunakan perspektif Normatif dan Sosiologis. Tujuan penelitian ini adalah untuk mengkaji lebih dalam formulasi hukum terhadap wasiat wajibah di Indonesia, baik pasal yang berlaku yaitu pasal 209 Kompilasi Hukum Islam, serta yurisprudensi wasiat wajibah dan perkembangan penerapannya.

Kata kunci: Wasiat Wajibah, Formulasi Hukum, Kompilasi Hukum Islam

\section{PENDAHULUAN}

Wasiat wajibah berada di antara wasiat dan waris. Dikatakan demikian, karena pewaris tidak perna secara eksplisit mewasiatkan kepada siapa harta peninggalnya diberikan, akan tetapi ada pihak tertentu selain ahli waris yang mendapatkan sebagian hartanya. Permasalahan wasiat wajibah tidak perna ditemukan di kitab-kitab klasik. permasalahan wasiat wajibah baru ada dalam kitab-kitab kontemporer setelah munculnya peraturan wasiat wajibah di Undang-Undang Perdata Mesir (Qānūn al-Madanì). Di dalam Undang-Undang Perdata Mesir, telah ditetapkan ketentuan wasiat wajibah yang diperuntukkan kepada para cucu dari anak yang telah meninggal dunia terlebih dahulu sebelum pewaris, sehingga tidak berhak mendapatkan warisan melalui proses hukum waris Islam karena terhijab oleh paman. ${ }^{1}$ Ketentuan tersebut kemudian diadopsi oleh negara-negara muslim lainnya.

1 Fahmi Al Amruzi, Rekontruksi Wasiat Wajibah Dalam Kompilasi Hukum Islam, (Yoyakarta: Aswaja Pressindo, 2014), hlm. vii. 
Kompilasi Hukum Islam (KHI) di Indonesia memberikan ketentuan hukum wasiat wajibah bukan kepada cucu yatim dari anak yang telah meninggal dunia seperti halnya di Mesir, yordania, maroko, dan negara-negara muslim lainnya. Masalah pemberian warisan kepada cucu yatim yang telah ditinggal oleh orangtuanya sebelum kakeknya sudah diatur dalam pasal 185 Kompilasi hukum Islam tentang ahli waris pengganti. Di Indonesia, ketentuan masalah wasiat wajibah diatur dalam pasal 209 Kompilasi Hukum Islam. Dalam pasal tersebut, dijelaskan bahwa wasiat wajibah ditujukan kepada anak angkat dan orang tua angkat.

Menurut hukum Islam, anak angkat mempunyai kedudukan yang berbeda dengan anak kandung yang berhak secara ijbari memperoleh harta warisan. Berdasarkan konteks hukum Islam awal, sangat jelas adanya larangan pengangkatan anak dengan menisbahkan namanya terhadap anak angkatnya. Budiarto dalam bukunya, "Pengangkatan Anak Ditinjau Dari Segi Hukum" mengatakan bahwa pengangkatan anak tidak membawa akibat hukum, baik dalam hal hubungan darah, dalam hak perwalian dan dalam hal hubungan waris mewarisi. ${ }^{2}$ Hal ini menimbulkan asumsi yang menyatakan bahwa ketentuan wasiat wajibah dalam pasal 209 Kompilasi Hukum Islam bertentangan dengan asas ijbari dalam hukum Islam, serta bertentangan dengan pelarangan menisbatkan anak angkat sebagai halnya anak kandung dalam hukum Islam. ${ }^{3}$

Atas dasar yang telah dipaparkan sebelumnya, penulis ingin menggali lebih dalam terhadap pasal 209 tentang wasiat wajibah dalam Kompilasi Hukum Islam untuk mengetahui formulasi hukum dari pasal tersebut dan juga perkembangan penerapan wasiat wajibah yang terjadi di Indonesia saat ini, guna menemukan format hukum yang tepat untuk diterapkan dewasa ini.

2 Ibid., hlm. 15.

3 Habiburrahman, Rekontruksi Hukum Kewarisan Islam di Indonesia, (Jakarta: Kencana, 2011), hlm. xv. 


\section{PEMBAHASAN}

\section{Wasiat Wajibah Menurut Hukum Islam}

Pada dasarnya, memberi wasiat adalah suatu tindakan ikhtiyari, yakni suatu tindakan yang dilakukan atas dorongan kemauan sendiri dalam keadaan apapun. Akan tetapi, penguasa atau hakim sebagai aparat negara, mempunyai wewenang untuk memaksa atau memberi surat putusan wajib wasiat yang terkenal dengan istilah wasiat wajibah kepada orang tertentu dan dalam keadaan tertentu. ${ }^{4}$ Oleh karena itu, pengertian wasiat wajibah secara umum adalah tindakan yang dilakukan oleh penguasa atau hakim sebagai aparat negara untuk memaksa, atau memberi putusan wajib wasiat bagi orang yang telah meninggal, diberikan kepada orang tertentu dan dalam keadaan tertentu. ${ }^{5}$

Setidaknya ada dua hal yang menjadi penyebab adanya wasiat wajibah. Pertama, hilangnya unsur ikhtiyar pemberi wasiat dan munculnya unsur kewajiban aparat negara (hakim) melalui sebuah peraturan undang-undang atau putusan wajib wasiat tanpa adanya kerelaan pewasiat dan persetujuan penerima wasiat. Kedua, adanya kemiripan dalam ketentuan pembagian harta warisan kepada anak laki-laki dan anak perempuan, yaitu 2:1.6 Kedudukan wasiat di dalam hukum kewarisan Islam, ditempatkan di atas hak para ahli waris dan setelah dilaksanakannya perawatan jenazah dengan harta peninggalannya serta pelunasan hutang orang yang meninggal. ${ }^{7}$

Dalil pokok tentang kewajiban berwasiat adalah surat AlBaqarah ayat 180:

$$
\text { كتب عليكم اذا حضر احدكم الموت ان ترك خير الوصية للو الدين والاقربين بالمعروف حقا على }
$$

4 Mardani, Hukum Kewarisan Islam di Indonesia, cet.ke-1, (Jakarta: Raja Grafindo Persada, 2014), hlm. 120.

5 Ibid.,

${ }^{6}$ Fathur Rahman, Ilmu Waris, (Bandung:Al-Ma'arif, 1981), hlm. 63.

7 Wahbah Zuhaili, Fiqih Imam Syafi'i: Mengupas Masalah Fiqhiyah Berdasarkan AlQur'an dan Hadits, (Jakarta: Al-mahira, 2010), hlm. 366. 
Artinya: "Diwajibkan atas kamu apabila seseorang di antara kamu jika dia meninggalkan harta, berwasiat untuk kedua orangtua dan karib kerabat dengan cara yang baik, (sebagai) kewajiban bagi orang-orang yang bertaqwa."

Sebagian ulama dalam menafsirkan ayat tersebut berpendapat bahwa wasiat kepada (orang tua dan kerabat) yang asalnya wajib, sampai sekarang masih tetap diberlakukan. Akan tetapi, Sebagian ulama berpendapat bahwa hukum wasiat kepada kerabat yang tidak mewarisi hanyalah sunnah, karena kewajiban berwasiat telah dimansukh oleh ayat-ayat kewarisan yang memberikan kepastian terhadap pembagian harta peninggalan. ${ }^{8}$

Para ulama berbeda pendapat mengenai wasiat wajibah karena adanya perbedaan pendapat dalam masalah mansukh atau tidaknya ayat Al-Quran dalam bidang kewarisan. Golongan yang mewajibkan wasiat kepada kerabat-kerabat yang tidak memperoleh warisan berpendapat bahwa ayat wasiat tersebut tidak mansukh, tetapi tetap berlaku sampai sekarang untuk kerabat yang tidak mendapatkan warisan karena ada suatu penghalang pewarisan atau ada orang yang lebih utama dari mereka. Oleh karena itu, wajib dibuatkan wasiat wajibah dengan nas wasiat, sedangkan untuk kerabat yang mendapat warisan dipergunakan ayat-ayat kewarisan. ${ }^{9}$ Selanjutnya, wasiat wajibah juga bersandar berdasarkan hadis yang melarang untuk memberi wasiat harta kekayaan kepada ahli warisnya sendiri menjelaskan konsep wasiat harta dalam islam ditujukan kepada kerabat jauh atau kerabat yang tidak mendapatkan hak waris. ${ }^{10}$

$$
\text { ان الله قد اعطى كل ذى حقه , فلا وصية لو ارث11 }
$$

8 Alyasa Abu Bakar, Ahli Waris Sepertalian Darah: Kajian Perbandingan Terhadap Penalaran Hazairin dan Penalaran Figh Madzhab, (Jakarta: INIS, 1998), hlm. 191.

${ }_{9}$ Ulama tersebut antaralain adalah Abu Bakar bin Abdul Aziz, Ibnu Hazim AzhZhahiri, Ath-Thabari dan Abu Muslim Al-Asbahani.

10 Sayuti Thalib, Hukum Kewarisan Islam di Indonesia, (Jakarta: Sinar Grafika, 2016), hlm. 131.

11 Muhammad Fu'ad Abdul Baqi, Al-Lu'lu wa Al-Marjan Bukhāri Wa Muslim, alih bahasa Abdul Rasyad Shiddiq, (Jakarta: Akbar Media Eka Sarana, 2013), I:442, Hadis Nomor 1057, "Kitab Wasiat," "Bab Meninggalkan Wasiat kepada Orang yang sebenarnya tidak berhak mendapatkan apa-apa." Diriwayatkan oleh al-Bukhari. 
Artinya: "sesungguhnya Allah telah memberi semua yang mempunyai hak akan haknya. Karena itu, tak ada wasiat untuk ahli waris"

Ibnu Hazm berpendapat, apabila tidak diadakan wasiat untuk kerabat dekat yang tidak mendapatkan warisan, maka hakim harus bertindak memberikan sebagian harta peninggalan kepada kerabatnya sebagai wasiat wajibah. Selanjutnya, dalam hal pengkhususan cucu-cucu sebagai kerabat yang tidak menerima warisan dan pembatasan penerimaan sebesar $1 / 3$ peninggalan didasarkan pada pendapat Ibnu Hazm dan Kaidah Fikih

إن لولي ألامر ان يأمر بالمباح لما ير اه من المصلحة العامة ومتى امربه وجبت طاعته

Artinya: "penguasa mempunyai wewenang memerintahkan perkara yang mubah karena ia berpendapat bahwa hal itu akan membawa kemaslahatan umum, bila penguasa menetapkan maka wajib mentaati."

Pada dasarnya, wasiat wajibah adalah sama-sama menggantikan tempat ahli waris yang meninggal terlebih dahulu sebelum pewaris meninggal dunia. Akan tetapi, ada perbedaan tentang jumlah penerimaan harta warisnya. Wasiat wajibah hanya menggantikan tempat orang yang meninggal, tetapi tidak menggantikan jumah penerimaan harta warisnya, oleh karena itu bagian yang diterimanya belum tentu sama dengan bagian yang semestinya diterima oleh yang diganti. Menurut Fahmi Al-Amruzi, dalam bukunya yang berjudul "Rekontruksi Wasiat Wajibah dalam Kompilasi Hukum Islam" mengatakan bahwa sebagian ahli hukum Islam, salah satunya yakni fathurrahman berpendapat bahwa wasiat wajibah diberikan hanya kepada cucu laki-laki dan perempuan yang orang tuanya telah meninggal. Selanjutnya Muhammad Zamro Muda menyatakan wasiat wajibah ialah sebagian dari harta peninggalan yang diperuntukkan oleh undang-undang untuk anakanak yang telah ditinggal mati ibu atau bapak sebelum kakek atau 
nenek karena dihijab oleh paman. ${ }^{12} \mathrm{Hal}$ ini sama dengan ketentuan wasiat wajibah yang diberlakukan di negara-negara muslim lain, seperti mesir, Iran, Syiria, Yordania dan negara-negara mayoritas muslim lainnya.

Di mesir, ketentuan wasiat wajibah diatur dalam pasal 76-78, Qanun Nomor 71 Tahun 1946. Pertama, wasiat wajibah diberikan kepada keturunan dari anak yang orang tuanya meninggal sebelum atau bersama-sama dengan pewaris atau kakeknya. Kedua, besarnya wasiat wajibah sebesar bagian yang harus diterima oleh anak pewaris ketika ia masih hidup sebelum pewaris meninggal, akan tetapi dengan batas maksimal 1/3 dari harta peninggalan. Ketiga, wasiat wajibah diberikan dengan syarat keturunan anak pewaris (cucu) bukan termasuk ahli waris, dan pewaris tidak perna memberikan sesuatu sebesar apa yang menjadi bagian anak tersebut, apabila ada perna pemberian, maka wajib digenapkan sampai kepada jumlah yang diwajibkan, dan apabila pemberian tersebut lebih kecil, maka harus digenapkan 1/3 dari harta peninggalan. Keempat, wasiat wajibah diperuntukan bagi cucu anak perempuan tingkat pertama dan cucu laki-laki dan seterusnya kebawah dari garis laki-laki. Kelima, apabila pewaris memberikan wasiat melebihi jumlah yang seharusnya, maka kelebihan tersebut merupakan wasiat ikhtiyariyyah, apabila jumlah wasiat tersebut lebih kecil, maka wajib digenapkan. Keenam, wasiat wajibah di dahulukan daripada wasiat yang lainnya. ${ }^{13}$ Ketentuan wasiat wajibah yang berlaku di Mesir tersebut kemudian diadopsi oleh negara-negara muslim lainnya, seperti Maroko, Kuwait, Syiria, Tunisia, Irak, Jordania dan Pakistan. Perbedaan mendasar mengenai ketentuan wasiat wajibah dari negara-negara tersebut adalah cucu mana sajakah yang berhak menerima wasiat wajibah.

12 Fahmi Al Amruzi, Rekontruksi Wasiat Wajibah Dalam Kompilasi Hukum Islam, hlm. 23-24.

13 Sri Hidayati, "Ketentuan Wasiat Wajibah di berbagai Negara Muslim Kontemporer", Jurnal Ilmu Syari'ah UIN Jakarta, tahun 2012 
Negara Maroko ${ }^{14}$ dan Kuwait ${ }^{15}$ memiliki ketentuan wasiat wajibah yang sama persis dengan Mesir. Negara Jordania16 memberikan wasiat wajibah hanya kepada cucu dari anak laki-laki dan seterusnya kebawah pada setiap generasi, sedangkan negara Syiria $^{17}$ hanya memberikan wasiat wajibah kepada cucu dari anak laki-laki generasi pertama saja, dan tidak berlaku untuk cucu dari anak laki-laki generasi seterusnya. Ketentuan cucu yang berhak mendapat wasiat wajibah di dua negara tersebut tidak memberikan wasiat wajibah kepada cucu dari anak perempuan, baik generasi pertama maupun seterusnya. Ketentuan ini sama seperti halnya dengan ketentuan wasiat wajibah yang diberlakukan di Mesir, Maroko dan Kuwait. Berbeda dengan negara-negara sebelumnya, di negara Irak ${ }^{18}$ dan Tunisia ${ }^{19}$ wasiat wajibah diberikan kepada cucu dari anak laki-laki dan perempuan dari generasi pertama, akan tetapi tidak berlaku untuk cucu dari anak laki-laki dan perempuan dari generasi kedua dan seterusnya. Ketentuan di negara Irak dan Tunisia lebih memandang kesetaraan derajat antara cucu dari anak laki-laki maupun perempuan dalam hal wasiat wajibah, oleh karena itu pemberian wasiat wajibah diberikan kepada cucu dari jalur laki-laki maupun perempuan.

Dalam wasiat wajibah, negara Pakistan tidak hanya berbeda mengenai cucu mana saja yang berhak mendapatkan wasiat wajibah, akan tetapi juga berbeda dalam hal bagian harta yang diterimanya. Pakistan mempunyai ketentuan bahwa semua cucu baik dari lakilaki maupun dari anak perempuan dapat menggantikan orangtua

14 Marocco Family Code, tahun 2004

15 Qānūn al Washiyyah al- Wajibah, Tahun 1971. Lihat Tahir Mahmood, Personal Law in Islamic Countries: History, Text and Comparative Analysis, (New Delhi: Academy Of Law and Religion, 1987), hlm. 148-149.

16 Pasal 182, Qānūn al- Ahwal Asy-Syakhsiyyah, Tahun 1976. Tahir Mahmood, Personal Law in Islamic Countries, hlm. 86.

17 Pasal 257 ayat 1, Qānūn al- Ahwal Asy-Syakhsiyyah, No. 59 Tahun 1953. Tahir Mahmood, Personal Law in Islamic Countries, hlm. 148-149.

18 Pasal 74, Qānūn al- Ahwal Asy-Syakhsiyyah, Tahun 1959. Tahir Mahmood, Personal Law in Islamic Countries, hlm. 163.

19 Pasal 191-192, Majallāt al-Ahkām al-Syakhsiyyah, tahun 1956. Tahir Mahmood, Personal Law in Islamic Countries, hlm. 162-163. 
yang telah meninggal, dan tidak terbatas pada cucu pertama saja, melainkan cucu generasi kedua dan seterusnya. Tidak hanya berbeda dalam hal cucu mana saja, Pakistan juga memberikan cucu tersebut bagian harta yang selaras dengan bagian yang akan diterima oleh anak pewaris apabila masih hidup, tanpa ada batasan 1/3. Konsep wasiat wasiat wajibah yang diberlakukan di Pakistan sama seperti halnya konsep ahli waris pengganti menurut khazairin. Konsep ahli waris pengganti kepada cucu yatim juga diberlakukan di Indonesia. ${ }^{20}$

Pada dasarnya, wasiat wajibah dan konsep ahli waris pengganti seperti yang dikemukakan oleh khazairin adalah samasama menggantikan tempat ahli waris yang meninggal terlebih dahulu sebelum pewaris meninggal dunia. Akan tetapi, wasiat wajibah hanya menggantikan tempat, sedangkan bagian yang diterimanya belum tentu sama dengan bagian yang semestinya diterima oleh yang diganti. Hal ini berbeda dengan konsep ahli waris pengganti yang menggantikan tempat pewaris sekaligus mendapatkan bagian harta waris yang setara dengan yang digantikannya.

\section{Wasiat Wajibah Menurut KHI dan Perkembangannya}

Pada dasarnya, tidak ada definisi secara formal mengenai wasiat wajibah dalam sistem hukum Islam di Indonesia, namun demikian Bismar Siregar mengungkapkan bahwa wasiat wajibah adalah suatu wasiat yang diperuntukkan kepada ahli waris atau kerabat yang tidak memperoleh bagian harta warisan karena adanya suatu halangan syara'. Eman suparman dalam bukunya berkomentar bahwa wasiat wajibah adalah wasiat yang pelaksanaanya tidak dipengaruhi atau tidak bergantung kepada kemauan dan kehendak pewaris. Kendati tidak adanya definisi tentang wasiat wajiabah, akan tetapi ketentuan wasiat wajibah termaktub dalam Kompilasi Hukum Islam (KHI)

20 Pasal 4, The Muslim Family Law Ordinance, Tahir Mahmood, Personal Law In Islamic Countries, hlm. 245. 
Wasiat wajibah merupakan salah satu bagian yang tercantum dalam Bab II yang mengatur tentang kewarisan dalam Kompilasi Hukum Islam (KHI). KHI dalam pasalnya tidak memperuntukkan wasiat wajibah kepada cucu yatim yang terhijab oleh paman seperti yang diterapkan di negara-negara lain. Pemberian hak waris untuk cucu yatim yang terhijab oleh paman telah tercakup dalam pengaturan tentang ahli waris pengganti dalam pasal 185 Kompilasi Hukum Islam (KHI).

Pasal 185 Kompilasi Hukum Islam:

a. Ahli waris yang meninggal lebih dahulu daripada si pewaris maka kedudukannya dapat digantikan oleh anaknya, kecuali mereka tersebut dalam pasal 173.

b. Bagian dari ahli waris pengganti tidak boleh melebihi dari bagian ahli waris yang sederajat dengan yang diganti ${ }^{21}$

Peraturan dalam pasal ini memberikan jaminan para cucu yang orang tuanya telah meninggal tidak akan terhijab oleh siapapun dan memiliki bagian yang jelas, yaitu setara dengan bagian orangtua yang digantikannya. Aturan masalah ahli waris pengganti juga temaktub dalam KUHPerdata yaitu dalam pasal 841 s/d 848. Ahli waris pengganti dalam KUHPerdata menduduki kedudukan orang tuanya secara mutlak, artinya segala hak dan kewajiban orang tuanya yang berkenaan dengan warisan beralih kepadanya. Ahli waris pengganti tidak hanya berlaku untuk anak dan cucu kebawah, tetapi juga ahli waris menyamping (kakak-adek dan anaknya) dan juga ahli waris menyilang (paman, bibi dan anaknya). ${ }^{22}$ Aturan ahli waris pengganti seperti ini, membuat konsep wasiat wajibah yang diberlakukan dinegara-negara muslim, yaitu untuk cucu yatim yang mahjub oleh paman tidak perlu lagi diberlakukan di Indonesia.

Dalam permasalahan wasiat wajibah, Kompilasi Hukum Islam mengaturnya dalam pasal 209, yaitu dengan ketentuan sebagai berikut:

${ }^{21}$ Kompilasi Hukum Islam, Pasal 185

22 Kitab Undang-Undang Hukum Perdata, Pasal 841 s/d 848. 
a. Harta Harta peninggalan anak angkat dibagi berdasarkan pasal-pasal 176 sampai dengan 193 tersebut di atas, sedangkan terhadap orang tua angkat yang tidak menerima wasiat diberi wasiat wajibah sebanyak-banyaknya $1 / 3$ dari harta warisan anak angkatnya

b. Terhadap anak angkat yang tidak menerima wasiat diberi wasiat wajibah sebanyak-banyaknya $1 / 3$ dari harta warisan orang tua angkatnya ${ }^{23}$

Di dalam Kompilasi Hukum Islam pasal 209 tidak dibahas dengan rinci syarat dan rukun dari wasiat wajibah. Akan tetapi, dengan melihat ketentuan dalam pasal tersebut dapat disimpulkan bahwa wasiat wajibah hanya diberikan kepada orang tua angkat atas anak angkatnya dan sebaliknya, anak angkat atas orang tua angkatnya. Adapun syarat wasiat wajibah bagi anak dan orang tua angkat tersebut adalah jika mereka tidak menerima wasiat ikhtiyari dari orangtua angkat atau anak angkat sebelum meninggal dunia.

Pada kenyataanya, penerapan wasiat wajibah yang terjadi di lapangan tidak hanya ditujukan kepada anak angkat seperti dalam pasal 209 Kompilasi Hukum Islam. Akan tetapi pemberian hak wasiat wajibah juga diberikan kepada anak kandung non muslim dan keluarga non muslim. Perkembangan dalam hak pemberian wasiat wajibah kepada keluarga non muslim tercermin melalui Ijtihad hakim dalam putusan Mahkamah Agung yang saat ini dijadikan sebagai yurisprudensi oleh para penegak hukum, akademisi hukum dan lain sebagainya. Putusan tersebut merupakan putusan Mahkamah Agung Nomor 368K/AG/199524, Nomor 51

23 Ibid., Pasal 209

24 Dalam kasus ini, pewaris memiliki 6 anak yang terdiri dari 3 anak laki dan 3 anak perempuan. Kelima anak beragama Islam dan satu anak beragama Kristen. Hakim memutuskan bahwa anak perempuan yang beragama kristen mendapatkan hak wasiat wajibah $3 / 4$ dari bagian anak perempuan, sedangkan ahli waris lainnya mendapatkan bagian antara laki-laki dan perempuan 1:2. 
K/AG/199925, Nomor $16 \mathrm{~K} / \mathrm{AG} / 2010^{26}$ dan Nomor 721K/AG/201527.

Pada dasarnya banyak sekali alternatif penyelesaian perkara dalam kewarisan yang tidak bisa diselesaikan ketika memahami hukum waris konvensional, bahkan banyak ahli waris yang lebih memilih cara kekeluargaan dan tidak mempersalahkan perbedaan agama di antara ahli waris. ${ }^{28}$ Perkembangan wasiat wajibah yang selama ini hanya sebatas anak angkat seperti dalam pasal $209 \mathrm{KHI}$ dan ahli waris yang berbeda agama seperti dalam putusan-putusan Mahkamah Agung, menjadi lebih luas dengan adanya putusan Mahkamah Agung Nomor 554 K/AG/ 2011. Putusan nomor 554 merupakan kasasi dari putusan Pengadilan Tinggi Maluku Utara nomor 1/Pdt.G/2011/PT.MU. Dalam putusan, hakim Mahkmah Agung memberikan hak waris kepada anak tiri melalui instrumen wasiat wajibah. Putusan ini dianggap sebagai suatu terobosan yang

25 Dalam kasus ini, pewaris tidak memiliki anak, tetapi pewaris meninggalkan 1 isteri beragama muslim, 3 saudara kandung beragama muslim dan 6 keponakan dari saudara yang sudah meninggal. Beberapa keponakan dari saudara yang telah meninggal beragama non muslim. Hakim memutuskan semua kerabat yang ditinggalkan baik muslim maupun non muslim mendapatkan harta warisan dengan rincian, isteri $1 / 4$ dari harta warisan, dan ahli waris lain mendapat $3 / 4$ bagian, termasuk ahli waris non muslim yang mendapatkan warisan melalui wasiat wajibah.

26 Dalam kasus ini, pewaris tidak memiliki anak, tetapi meninggalkan isteri beragama non muslim, seorang ibu beragama muslim dan 4 saudara kandung yang beragama muslim. Mahkama Agung memutuskan bahwa isteri pewaris berhak mendapatkan warisan melalui wasiat wajibah sebesar $1 / 4$ dan ditambah $1 / 2$ bagian dari harta bersama. Sedangkan ahli waris yang beragama muslim mendapatkan $1 / 5$ bagian, dengan perbandingan 1:2 untuk laki-laki dan perempuan.

27 Dalam kasus ini, pewaris meninggalkan seorang isteri beragama muslim dan dua anak yang beragama non muslim. Mahkamah Agung memutuskan bahwa isteri pewaris menerima $1 / 2$ bagian dari harta warisan ditambah $7 / 24$ bagian dari harta bersama. Sedangkan kedua anaknya mendapatkan 17/24 bagian dari harta peninggalan setelah dilunasi hutang-hutangnya.

28 Euis Muflihah, "Tinjauan Hukum Islam Terhadap Pembagian Waris Beda Agama: Studi Kasus di Desa Merdikorejo Kecamatan Tempel Kabupaten Sleman", Skripsi Fakutas Syari'ah dan Hukum Universitas Islam Negeri Sunan Kalijaga Yogyakarta, 2002, hlm. 54. 
sangat progresif dalam perspektif pengembangan hukum wasiat wajibah. ${ }^{29}$

Kontradiksi yang terjadi dalam putusan hakim tentang pemberian wasiat wajibah kepada anak tiri muncul ketika terdapat putusan hakim tingkat banding Nomer 03/Pdt.G/2016/PTA.Jb dan putusan hakim tingkat kasasi Nomor 733K/Ag/2016 yang membatalkan pemberian wasiat wajibah kepada anak tiri oleh putusan hakim tingkat pertama dengan nomor register 192/Pdt.G/2015/PA.sgt.

Majelis hakim pada tingkat pertama memberikan wasiat wajibah kepada anak tiri dengan tujuan untuk memberikan keadilan bagi para pihak yang berkara dengan melihat dari segi syar'i dan sosiologis, sedangkan Majelis hakim pada tingkat banding dan kasasi berpendapat bahwa pemberian wasiat wajibah kepada anak tiri harus dilihat dari segi yuridis sesuai ketentuan undang-undang maupun Kompilasi Hukum Islam dan juga fakta-fakta hukum.

\section{Analisis Formulasi Hukum Wasiat Wajibah dalam KHI dan Perkembangan Penerapanya}

Saat ini satu-satunya dasar hukum materiil kewarisan Islam di Indonesia adalah Kompilasi Hukum Islam yang dijelaskan dalam Bab II, walaupun status Kompilasi Hukum Islam hanya berupa Inpres yang disahkan pada 10 Juni 1991. Pengaturan wasiat wajibah secara sempit diatur dalam pasal 209 Kompilasi Hukum Islam, yaitu hanya diperuntukkan kepada anak angkat dan orang tua angkat. Di negara mayoritas muslim seperti Mesir, Yordania, Irak dan lain-lain, wasiat wajibah diperuntukkan kepada cucu yatim yang ditinggal mati oleh orang tuanya sehingga cucu tersebut terhijab oleh paman. Indonesia merupakan negara hukum, dimana hukum Indonesia tidak hanya bersumber pada satu hukum saja, melainkan mengandung prinsip hukum lainnya, seperti hukum adat, hukum agama dan juga kondisi sosial budaya, serta mengedapankan asas

29 Wiwin, "Pengembangan Hukum Wasiat Wajibah Terhadap Anak Tiri: Studi Analisis Putusan MA No:554 K/ AG/2011" tgl 19 Maret 2012, Jurnal Universitas Muhammadiyyah Surabaya Tahun 2018. 
keadilan sosial bagi seluruh masyarakat. Hal ini menyebabkan ketentuan-ketentuan dalam Kompilasi Hukum Islam seakan-akan bertentangan dengan hukum Islam, karena memperuntukkan wasiat wajibah kepada anak angkat dan orang tua angkat sebesar 1/3 bagian.

Pada dasarnya pengakuan anak angkat seperti anak kandung sendiri merupakan kebiasaan masyarakat jahiliyah, dengan menasabkan anak angkat pada orang tua angkatnya. Pemberian hak waris kepada anak angkat juga merupakan aturan kewarisan yang diberlakukan pada masa jahiliyah, dimana pada masa itu ahli waris terdiri dari tiga golongan. Pertama kepada keluarga dengan hubungan nasab, tetapi dengan ketentuan hanya untuk anak laki-laki yang sudah dewasa saja. Kedua, kewarisan karena sumpah setia. Ketiga karena pengangkatan anak. Akan tetapi turunnya ayat Allah dalam al-Qur'an secara tegas telah melarang merubah nasab anak angkat kepada orang tua angkatnya. ${ }^{30}$

Dalam prakteknya, anak angkat dalam hukum adat di Indonesia maupun dalam Undang-undang Perlindungan Anak, diperlakukan sebagai mana orang tua memperlakukan anak kandung. Hal ini dikarenakan anak angkat banyak berjasa memelihara orang tua angkatnya. Tidak hanya itu, pengangkatan anak di Indonesia juga didasari dengan rasa kasih sayang untuk menjadi anaknya sendiri, tanpa embel-embel sebagai anak angkat.

Konsep yang mendasar dalam pasal 209 Kompilasi Hukum Islam adalah hadis tentang wasiat yang lebih mengutamakan orang lain yang bukan ahli waris, sedang orang lain tersebut yang paling tepat adalah anak angkat. Konsep wasiat harta dalam Islam, ditujukan kepada kerabat jauh, atau kerabat yang tidak mendapat hak waris, dan juga orang lain. Atas dasar ini pula Kompilasi Hukum Islam menunjuk wasiat wajibah untuk anak angkat dan orang tua angkat, bukan kepada cucu yang terhijab.

$$
\text { ان الله قد اعطى كل ذى حقه , فلا وصية لو ارث }
$$

30 Hasanain M. Makhluf, al-Mawaris fi asy-Syari'ah al-Islamiyah, (Kairo Mesir: Mathba'ah al-Madani, 1976), hlm. 4-6. 
Berdasarkan uraian di atas, diketahui bahwa dasar pertimbangan hukum mengenai hak waris anak angkat atau wasiat wajibah di dalam Kompilasi Hukum Islam bukan hanya berdasarkan landasan syari'ah tentang anjuran berwasiat kepada selain ahli waris, tetapi juga mempertimbangkan tentang maslahah mursalah, hukum Adat dan sosial budaya di Indonesia. Meskipun demikian, perlu kita ingat bahwa yurisprudensi di pengadilan Agama juga menunjukkan disparitas bagian wasiat wajibah bagi anak angkat. Hal ini terjadi ketika majelis hakim tidak mau repot dengan serta merta memberikan hak waris bagi penerima wasiat wajibah sebesar 1/3 bagian dari harta pewaris tanpa mempertimbangkan apakah pemberian maksimal tersebut telah merampas hak-hak ahli waris lainnya atau tidak. Oleh karena itu, kebijakan majelis hakim dalam memberikan bagian wasiat wajibah disini menjadi instrument yang sangat penting guna mewujudkan keadilan dan kemaslahatan bersama. Tidak jarang sebagian hakim memberikan bagian wasiat wajibah tidak melebihi bagian terkecil dari ahli waris.

Apabila kita menela'ah pendapat ulama fikih terhadap ahli waris non muslim, tentu saja jumhur ulama sepakat berpendapat bahwa perbedaan agama merupakan penghalang kewarisan, meskipun terdapat beberapa ulama kontemporer yang berpendapat bahwa orang muslim boleh mewarisi harta dari orang non muslim. Tidak dapat dipungkiri, adanya yurisprudensi pemberian wasiat wajibah kepada ahli waris non muslim pada beberapa putusan Mahkama Agung tentu saja membentuk ketentuan hukum baru meskipun belum tertulis dalam peraturan perundang-undangan manapun.

Di dalam Kompilasi Hukum Islam (KHI) pasal 171 secara tersirat menyatakan bahwa perbedaan agama merupakan penghalang untuk mendapatkan warisan, akan tetapi di dalam pasal 173 KHI perbedaan agama tidak disebutkan dalam pembahasan tentang hal-hal yang menghalangi kewarisan. Di dalam BW dan hukum adat, perbedaan agama bukan merupakan suatu hal yang dapat menghalangi pewarisan. Wasiat wajibah untuk ahli waris non 
muslim menurut pendapat Ibnu Hazm, merupakan sarana untuk menjembatani kesenjangan antara hukum Islam dan Hukum Adat, karena sebagian besar masyarakat Indonesia tidak bisa dipisahkan dengan Hukum Adat. Maka, berdasarkan hukum adat dengan asas keadilan, sosial dan kemasusiaan diberikan wasiat wajibah untuk ahli waris yang berbeda Agama seperti halnya putusan Mahkamah Agung.

dalam bentuk studi Islam di dalam pendekatan sosiologi hukum Islam, terdapat satu studi tentang pengaruh struktur dan perubahan masyarakat terhadap pemahaman ajaran agama atau konsep keagamaan. ${ }^{31}$ Studi ini menjelaskan bahwa perubahan masyarakat berpengaruh terhadap pemikiran dan pemahaman agama. Pendekatan ini mengingatkan penulis pada sebuah teori perubahan hukum dari Ibn Qayim al-Jauziyah.

تغير الفتوى واختلا فها بحسب تغير ألا زمنة و الامكنة والا حوال والنيات والعو ائد

Artinya: "perubahan dan perbedaan fatwa sesuai dengan berubahnya waktu, tempat, kondisi, niat dan adat"

Ibn Qayim al-Jauziyah menjelaskan bahwa perubahan hukum dan perubahan sosial adalah sebuah fenomena yang saling mempengaruhi antara satu dengan yang lainnya. Perubahan hukum dalam suatu negara dapat mempengaruhi perubahan sosial masyarakat, begitu pula perubahan sosial masyarakat dapat membawa kepada perubahan hukum dalam suatu negara. ${ }^{32}$ Seperti halnya lahirnya qaul qadim dan qaul jadid bagi Imam Syafi'I yang terjadi karena perbedaan geografis Basrah dan Mesir. Sebagai contoh kongkritnya, yaitu fatwa ulama tergabung dalam organisasi yang dekat dengan pemerintah akan menghasilkan ketentuan hukum yang berbeda dengan lembaga fatwa yang bersifat independen. Hal ini terjadi karena perbedaan struktur sosial yang mereka tempati. ${ }^{33}$

31 Amin Abdullah Dkk, Rekontruksi Metodologi Ilmu-Ilmu Keislaman, (Yogyakarta: SUKA-Press, t.t.), hlm. 177.

32 Syamsulbahri Salihima, Perkembangan Pemikiran Pembagian Warisan dalam Hukum Islam dan Implementasinya pada Pengadilan Agama, cet.ke-2, (Jakarta: Kencana, 2016), hlm.17-18.

${ }^{33}$ Mohammad Shodik, "Sosiologi Hukum Islam", Hand Out Fakultas Syari'ah dan Hukum Universitas Islam Negeri Sunan Kalijaga Yogyakarta, (2013), hlm.177. 
Menurut penulis, pemberian wasiat wajibah kepada anak angkat merupakan peraturan yang sudah tepat dan relevan di Indonesia dengan dasar-dasar sosiologi yang telah dipaparkan di atas, serta telah diberlakukanya konsep ahli waris pengganti (khazairin) bagi cucu laki-laki maupun perempuan yang orangtuanya telah meninggal terlebih dahulu. Di Indonesia, Anak angkat adalah anak yang secara sengaja diambil karena kepentingan orang tua angkat dan anak angkat itu sendiri, yakni pengganti anak kandung dalam tujuan kasih sayang. Oleh karena itu, wajar jika anak angkat memperoleh harta dari orang tua angkat. Di sisi lain, alQur'an secara tegas telah melarang merubah nasab anak angkat kepada orang tua angkatnya. Akan tetapi pemberian wasiat wajibah dalam hal ini bukan berarti menisbatkan nasab baru terhadap anak angkat, melainkan sebagai pemberian hak dari harta warisan karena telah menjadi anak yang sah secara hukum dan dekat secara batin pada orangtua angkatnya.

Keputusan hakim memberikan wasiat wajibah kepada anak kandung non muslim atau keluarga non muslim, merupakan terobosan hukum melauli ijtihad hakim untuk senantiasa memberikan keadilan kepada keluarga non muslim dengan pertimbangan hubungan keluarga dengan pewaris semasa hidup dan melihat bagaimana sikap serta iktikadnya. ${ }^{34}$ Disisi lain ulama tafsir, hadis dan fikih sepakat, bahwa perbedaan agama merupakan salah satu dari penghalang untuk mendapatkan warisan, namun di dalam Kompilasi Hukum Islam, perbedaan agama tidak disebutkan menjadi salah satu penyebab terhalangnya kewarisan. Di dalam pasal 173 Kompilasi Hukum Islam dikatakan bahwa, seorang terhalang menjadi ahli waris apabila membunuh atau mencoba membunuh (dalam poin a), dipermasalahkan secara memfitnah telah mengajukan pengaduan bahwa pewaris telah melakukan suatu kejahatan yang diancam dengan hukuman lima tahun penjara atau

34 Mastukha, "Wasiat Wajibah Bagi Non Muslim : Analisis Terhadap Pemikiran Hukum Imam Ibnu Hazm", Skripsi Fakultas Syari'ah dan Hukum Universitas Islam Negeri Sunan Kalijaga Yogyakarta, 2012, hlm. 65. 
lebih (di dalam poin b). ${ }^{35}$ Oleh karena itu, pemberian wasiat wajibah kepada anak atau keluarga non muslim merupakan cara yang paling baik untuk diterapkan sebagai bentuk pemberian keadilan dan tidak melanggar hukum tertulis Indonesia, dalam hal ini Kompilasi Hukum Islam.

Menurut penulis, Putusan Mahkamah Agung tentang pemberian wasiat wajibah bagi kerabat non muslim merupakan putusan yang cukup akomodatif terhadap suasana demoktratis dalam hidup bermasyarakat dan bernegara. Putusan ini dianggap mampu menjawab kebutuhan akan rasa keadilan yang menjadi hak milik setiap individu. Putusan ini juga bisa dikatakan relevan dengan hukum Islam di Indonesia.

Dalam permasalahan wasiat wajibah yang diperuntukkan untuk anak tiri seperti dalam putusan Mahkamah Agung Nomor 554 K/AG/2011, hakim menjadikan ayat 180 surat al-Baqarah sebagai dasar hukum atas kewajiban berwasiat. Pada dasarnya, kewarisan atau wasiat wajibah tidak diperuntukkan kepada anak tiri maupun ibu tiri. Salah satu alternatif pemberian harta waris adalah dengan jalur hibah dan wasiat, bukan dengan wasiat wajibah. Lebih kuatnya posisi anak angkat yang sama sekali tidak mempunyai hubungan darah daripada anak tiri yang mempunyai satu hubungan darah, menjadikan masalah kewarisan anak tiri perlu diperhatikan untuk kesejahteraan anak. Apalagi ketika anak tiri tersebut tidak mendapatkan hibah maupun wasiat dari orang tua tirinya.

Putusan hakim tingkat banding Nomer 03/Pdt.G/2016/PTA.Jb dan putusan hakim tingkat kasasi Nomor 733K/Ag/2016 yang membatalkan pemberian wasiat wajibah kepada anak tiri oleh putusan hakim tingkat pertama dengan nomor register 192/Pdt.G/2015/PA.sgt. merupakan keabsahan dalam sebuah pengkajian hukum. Hukum adalah apa yang dianggap seorang mujtahid itu benar, oleh karena itu perbedaan pendapat diantara penegak hukum adalah suatu yang sah. Seperti halnya

35 Habiburrahman, Rekontruksi Hukum Kewarisan Islam di Indonesia, hlm. 78. 
dengan salah satu fitur dalam teori Sistem Hukum Islam yang dikemukakan oleh Jaser 'Audah, yaitu watak kognisi. ${ }^{36}$ Setiap mujtahid, yang dalam kasus ini adalah Hakim mempunyai watak kognisi (akal/pemikiran) yang berbeda-beda sesuai keilmuan, baground, sudut pandang, sosial dan budaya, sehingga perbedaan pendapat antara satu dengan lainnya adalah sesuatu yang tidak mustahil terjadi. Disatu sisi, majelis hakim tingkat banding dan kasasi mempertimbangkan kepastian hukum melalui pertimbangan yuridis yaitu perundang-undangan, dalam hal ini Kompilasi Hukum Islam, sedangkan di sisi lain majelis hakim tingkat pertama lebih mempertimbangkan keadilan melalui pertimbangan sosiologis. Dua sudut pandang yang berbeda dalam melihat suatu persoalan, dapat menghasilkan dua pemikiran yang berbeda juga.

Menurut penulis, pemberian wasiat wajibah kepada anak tiri seperti halnya yang dilakukan oleh hakim PA tingkat pertama dalam putusan nomor register 192/Pdt.G/2015/PA.sgt adalah hal yang perlu dikaji ulang secara mendalam. Ketiadaan hukum karena hukum tersebut tidak tertulis dan tercantum dalam kodifikasi hukum, bukan berarti keadilan tidak perlu ditegakkan dalam masyarakat. Keadilan juga dapat dicapai melalui norma dan kaidah hidup di dalam masyarakat. Dalam hukum adat, permasalahan pemberian hak dari harta warisan kepada nak tiri yang hidup bersama dengan orang tua tirinya dapat diberikan hak asuh atau hak pelihara. Hak asuh dan hak pelihara ini telah diakui oleh adat, agama dan juga keluarga yang bersangkutan. Secara logika akal, kedekatan dalam hal keluarga (bukan nasab) lebih mendekati anak tiri daripada anak angkat, sedangkan anak angkat dan orangtua angkat telah tertulis bagiannya dalan Kompilasi Hukum Islam.

Seorang mujtahid berhak melakukan ijtihad selama tidak bertentangan dengan ijma' para mujtahid atau mayoritas mujtahid. Ketika terjadi sengketa hukum dalam masyarakat, hakim tidak boleh

36 Jāsir 'Audah, Maqasid al-Shariah as Philosophy of Islamic Law a System Approach, (London: The International Insitute of Thought, 2007), hlm.33. 
menolak dengan alasan bahwa Undang-undang belum mengaturnya. Apabila hakim tidak menemukan landasan hukum yang tertulis, maka hakim harus menggali lebih dalam untuk menemukan hukum, baik dari hukum yang hidup di masyarakat, hukum adat dan melalui nilai-nilai agama. Hal ini sesuai dengan ketentuan dalam pasal 16 ayat 1 dan 2 Undang-undang Nomor 14 Tahun 2004 tentang kekuasaan kehakiman.

Penulis berpendapat bahwa jalan yang bisa ditempuh untuk kesejahteraan anak tiri dalam hal ini adalah dengan jalur qiyas. ${ }^{37}$ Jalur qiyas ini merupakan terobosan hukum wasiat wajibah kepada anak tiri dengan mengkaitkan hak wasiat wajibah anak angkat yang ditetapkan KHI demi kemaslahatan untuk melindungi dan menjamin kesejahteraan anak tiri yang ada di dalam tanggung jawab suatu keluarga. Pada dasarnya, hasil qiyas ini akan memiliki fungsi yang sama dengan pemberian porsi anak angkat sebagai wasiat wajibah dengan alasan anak angkat dan anak tiri mempunyai persamaan illat. Illat antara anak angkat dan anak tiri adalah anak orang lain yang dengan sengaja dimasukkan menjadi bagian dari satu keluarga. Akan tetapi, anak tiri tersebut harusnya anak tiri yang berbakti kepada orang tuanya dan mempunyai kedekatan secara psikologis dengan orang tua tirinya.

\section{KESIMPULAN}

Wasiat wajibah merupakan adalah tindakan yang dilakukan oleh penguasa atau hakim sebagai aparat negara untuk memaksa, atau memberi putusan wajib wasiat bagi orang yang telah meninggal, diberikan kepada orang tertentu dan dalam keadaan tertentu. Pemberian wasiat wajibah kepada anak angkat merupakan peraturan yang sudah tepat dan relevan di Indonesia atas dasardasar sosiologi (kedekatan psikologi antara anak angkat dengan orang tua angkat), dasar hukum Islam tentang wasiat bukan kepada

${ }^{37}$ Marsiani, “Wasiat Wajibah Untuk Anak Tiri: Analisis terhadap Ketentuan dalam KHI", Skripsi Fakultas Syari'ah dan Hukum Universitas Islam Negeri Sunan Kalijaga Yogyakarta, 2016, hlm.80-81. 
ahli waris dan diberlakukanya ahli waris pengganti (khazairin) oleh cucu laki-laki maupun perempuan yang or angtuanya telah meninggal terlebih dahulu.

Wasiat wajibah yang diperuntukkan kepada ahli waris non muslim bersandar pada hukum adat dengan asas kedilan, sosial dan kemasusiaan. wasiat wajibah bagi kerabat non muslim juga cukup akomodatif terhadap suasana demoktratis dalam hidup bermasyarakat dan bernegara untuk menjawab kebutuhan akan rasa keadilan yang menjadi hak milik setiap individu dan menghindari kesenjangan ditengah masyarakat indonesia yang majemuk.

Pemberian wasiat wajibah untuk anak tiri bisa dilakukan dengan jalan mengqiyaskan antara anak tiri dengan anak angkat dengan illat bahwa anak angkat dan anak tiri adalah anak orang lain yang dengan sengaja dimasukkan menjadi bagian dari satu keluarga. Akan tetapi dengan catatan, anak tiri tersebut adalah anak yang berbakti dan mempunyai kedekatan psikologi dengan orang tuanya. Akan tetapi pemberian wasiat wajibah kepada anak tiri perlu pengkajian lebih mandalam oleh pihak-pihak yang berwenang dalam masalah ini.

Wasiat wajibah dalam KHI dan yang berlaku di Indonesia, pada umumnya merupakan pluralisme dari hukum Islam dan Hukum Adat yang bersandar pada asas keadilan dan keseimbangan guna memberikan kemaslahatan bagi seluruh masyarakat

\section{DAFTAR PUSTAKA}

Abdullah. Amin Dkk, Rekontruksi Metodologi Ilmu-Ilmu Keislaman, Yogyakarta: SUKA-Press, t.t.

Amruzi. Fahmi Al, Rekontruksi Wasiat Wajibah Dalam Kompilasi Hukum Islam, Yoyakarta: Aswaja Pressindo, 2014.

'Audah. Jāsir, Maqasid al-Shariah as Philosophy of Islamic Law a System Approach, London: The International Insitute of Thought, 2007. 
Bakar. Alyasa Abu, Ahli Waris Sepertalian Darah: Kajian Perbandingan Terhadap Penalaran Hazairin dan Penalaran Figh Madzhab, Jakarta: INIS, 1998.

Baqi. Muhammad Fu'ad Abdul, Al-Lu'lu wa Al-Marjan Bukhāri Wa Muslim, alih bahasa Abdul Rasyad Shiddiq, (Jakarta: Akbar Media Eka Sarana, 2013)

Habiburrahman, Rekontruksi Hukum Kewarisan Islam di Indonesia, Jakarta: Kencana, 2011.

Hidayati, Sri, Ketentuan Wasiat Wajibah di berbagai Negara Muslim Kontemporer, Jurnal Ilmu Syari'ah UIN Jakarta, tahun 2012

Kitab Undang-undang Hukum Perdata

Mahmood, Tahir, Personal Law In Islamic Countries: History, Text and Comparative Analysis, New Delhi: Academy Of Law and Religion, 1987.

Makhluf. Hasanain M, al-Mawaris fi asy-Syari'ah al-Islamiyah, (Kairo Mesir: Mathba'ah al-Madani, 1976

Mardani, Hukum Kewarisan Islam di Indonesia, cet.ke-1, Jakarta: Raja Grafindo Persada, 2014.

Marocco Family Code, tahun 2004

Marsiani, "Wasiat Wajibah Untuk Anak Tiri: Analisis terhadap Ketentuan dalam KHI", Skripsi Fakultas Syari'ah dan Hukum Universitas Islam Negeri Sunan Kalijaga Yogyakarta, 2016.

Mastukha, "Wasiat Wajibah Bagi Non Muslim: Analisis Terhadap Pemikiran Hukum Imam Ibnu Hazm", Skripsi Fakultas Syari'ah dan Hukum Universitas Islam Negeri Sunan Kalijaga Yogyakarta, 2012.

Muflihah. Euis, “Tinjauan Hukum Islam Terhadap Pembagian Waris Beda Agama: Studi Kasus di Desa Merdikorejo Kecamatan Tempel Kabupaten Sleman", Skripsi Fakutas Syari'ah dan 
Hukum Universitas Islam Negeri Sunan Kalijaga Yogyakarta, 2002.

Putusan Mahkamah Agung Nomor 192/Pdt.G/2015/PA.sgt

Putusan Mahkamah Agung Nomor 368K/AG/1995

Putusan Mahkamah Agung Nomor Nomor 16 K/AG/2010

Putusan Mahkamah Agung Nomor Nomor 51 K/AG/1999

Putusan Mahkamah Agung Nomor Nomor 554 K/ AG/ 2011

Putusan Mahkamah Agung Nomor Nomor 721K/AG/2015

Putusan Mahkamah Agung Nomor Nomor 733K/Ag/2016

Rahman. Fathur, Ilmu Waris, Bandung: Al-Ma'arif, 1981.

Salihima. Syamsulbahri, Perkembangan Pemikiran Pembagian Warisan dalam Hukum Islam dan Implementasinya pada Pengadilan Agama, cet.ke-2, Jakarta: Kencana, 2016.

Shodik. Mohammad, "Sosiologi Hukum Islam", Hand Out Fakultas Syari'ah dan Hukum Universitas Islam Negeri Sunan Kalijaga Yogyakarta, (2013)

Thalib. Sayuti, Hukum Kewarisan Islam di Indonesia, Jakarta: Sinar Grafika, 2016.

Undang-undang Nomor 14 Tahun 2004 tentang kekuasaan kehakiman.

Undang-Undang Republik Indonesia Nomor 1 Tahun 1974 dan Kompilasi Hukum Islam, Bandung: Citra Umbara, 2015.

Wiwin, Pengembangan Hukum Wasiat Wajibah Terhadap Anak Tiri: Studi Analisis Putusan MA No:554 K/ AG/2011 tgl 19 Maret 2012, Jurnal Universitas Muhammadiyyah Surabaya, 2018.

Zuhaili, Wahbah, Fiqih Imam Syafi'i: Mengupas Masalah Fiqhiyah Berdasarkan Al-Qur'an dan Hadits, Jakarta: Al-mahira, 2010. 